\title{
PENGARUH RELASI FRANCHISE TERHADAP PENINGKATKAN PERFORMA FRANCHISEE (Studi pada Franchisee Ayam Bakar Mas Mono, Pecel Lele Lela dan Es Teler 77 di Wilayah Jabodetabek)
}

\author{
Dedik Supardiono*) \\ email : dediksoe@yahoo.com
}

\begin{abstract}
ABSTRAK
Studi ini dilakukan untuk menguji pengaruh aspek kontrak kerjasama, aktivitas manajerial, entrepreneurship dan branding (pengelolaan merek) terhadap relasi franchise dalam meningkatkan performa franchisee. Pengambilan sampel memakai teknik purposive, dan didapatkan sampel sejumlah 107 dari franchisee Restoran Ayam Bakar Mas Mono, Restoran Pecel Lele Lela dan Restoran Es Teler 77. Seluruh franchisee berlokasi di Jabodetabek. Adapun hipotesis penelitian ini adalah semakin besar nilai kontrak kerjasama, aktivitas manajerial, entrepreneurship dan branding akan semakin meningkatkan relasi franchise, dan semakin tinggi nilai relasi franchise maka akan semakin tinggi pula performa franchisee. Analisis data dengan menggunakan software SPSS 20 dan Lisrel 8.7 Student Version. Hasil analisis menunjukkan bahwa kontrak kerjasama, aktivitas manajerial, entrepreneurship dan branding berpengaruh positif dan signifikan terhadap relasi franchise, dan relasi franchise berpengaruh positif dan signifikan terhadap performa franchisee. Temuan empiris dalam studi ini mengindikasikan bahwa untuk meningkatkan performa franchisee diperlukan peningkatan faktor-faktor kontrak kerjasama, aktivitas manajerial, entrepreneurship dan branding serta relasi hubungan franchise.
\end{abstract}

Kata kunci : Franchise, Franchisor, Franchisee, Perjanjian Kerjasama, Aktivitas Manajerial, Entrepreneurship, Branding, Relasi Franchise, Performa Franchisee.

\section{ABSTRACT}

The motive of this study was to examine the extent of the effect of the franchise contract, management, motivation of entrepreneur, and brand management that have impact on franchise relation to enhance of performance of franchisee.

By using research purposive sampling method, which aims to describe and examine the relationship and causality between the two or more variables and for the samples taken were 107 respondents. All of respondents are franchisee of Ayam Bakar Mas Mono, Pecel Lele Lela and Es Teler 77, in Jabodetabek areas. Data analysis with software SPSS 20 and Lisrel 8.7 Student Version. Hypothesis testing results show that (1) Franchise Contract express sure and eloquent effect on Franchise Relation. (2) Management aspect express sure and eloquent effect on Franchise Relation (3) Motivation of Entrepreneur express sure and eloquent effect on Franchise Relation (4) Brand Management express sure and eloquent effect on Franchise Relation (5) Franchise Relation express sure and eloquent effect to Enhance of Performance of Franchesee.

Keywords: Franchise, Franchisor, Franchisee, Franchise Contract, Management, Motivation of Entrepreneur, Brand Management 


\section{A. Pendahuluan}

Tren bisnis dan perekonomian yang berkembang di seluruh dunia saat ini adalah franchise atau waralaba. Franchise yang pada awalnya berkembang di Amerika telah meluas ke seluruh pelosok dunia. Produk-produk dari perusahaan yang bergerak dibidang franchise telah dinikmati masyarakat dunia dan menjadi gaya hidup global. Disisi lain, franchise telah mendekatkan masyarakat dunia dengan menggerakkan perekonomian dan tenaga kerja.

Ayam Bakar Mas Mono, Pecel Lele Lela dan Es teler 77 merupakan perusahaan franchise di Indonesia yang sedang tumbuh dengan melibatkan masyarakat untuk menjadi franchiseenya. Kompetisi bisnis kuliner yang semakin kompetitif memaksa franchisor terus berbenah ke arah yang lebih profesional, sehingga pihak franchisee bisa merasakan keuntungan yang optimal dalam menjalankan bisnis franchise.

Studi yang mendalam tentang sistem franchise, terutama tentang aspek yang dapat meningkatkan kualitas relasi antara franchisor dan franchisee untuk meningkatkan performa franchisee diharapkan mampu meningkatkan tingkat keberhasilan franchisee baru di Indonesia.

\section{B. Perumusan Masalah}

Berdasarkan uraian di atas, dapat dirumuskan permasalahan dalam studi ini sebagai berikut:

1. Bagaimanakah aspek kontrak kerjasama, aktivitas manajerial, entrepreneurship, dan branding berpengaruh terhadap relasi franchise Ayam Bakar Mas Mono, Restoran Pecel Lele Lela dan Restoran Es Teler 77?

2. Apakah terdapat pengaruh relasi franchise Ayam Bakar Mas Mono, Restoran Pecel Lele Lela dan Restoran Es Teler 77 terhadap performa franchisee?

\section{Tujuan Studi}

Adapun tujuan studi ini adalah sebagai berikut :

1. Menganalisis pengaruh aspek kontrak kerjasama, aktivitas manajerial, entrepreneurship, dan branding terhadap relasi franchise Restoran Ayam Bakar Mas Mono, Restoran Pecel Lele Lela dan Restoran Es Teler 77.

2. Menganalisis pengaruh relasi franchise Ayam Bakar Mas Mono, Restoran Pecel Lele Lela dan Restoran Es Teler 77 terhadap performa franchisee.

\section{Landasan Teori \\ Franchise}

Bisnis franchise pertama kali berkembang di Perancis, oleh karena itu kata franchise berasal dari bahasa Perancis affranchir yang berarti to free yang artinya membebaskan. Dalam bidang dunia bisnis kata franchise berarti kebebasan yang dapat diperoleh entrepreneur dalam menjalankan sendiri suatu usaha yang dipilihnya sendiri di daerah yang dikehendakinya sendiri. (Bradach. 1998).

Dalam pengertian kata franchise, perlu diterangkan apa yang dimaksud dengan franchisor dan franchisee, sebagai berikut (Sukandar. 2006) :

- Franchisor atau pemberi waralaba adalah badan usaha atau perorangan yang memberikan hak kepada pihak lain untuk memanfaatkan dan atau menggunakan hak atas kekayaan intelektual atau penemuan atau ciri khas usaha yang dimilikinya. 
- Franchisee atau penerima waralaba adalah badan usaha atau perorangan yang diberikan hak untuk memanfaatkan dan atau menggunakan hak atas kekayaan intelektual atau penemuan atau ciri khas yang dimiliki pemberi waralaba atau franchisor.

\section{Aspek Relasi Franchise}

Kontrak kerjasama dalam sistem franchise merupakan bentuk transaksi atau pertukaran bisnis, dan dapat dimasukkan dalam hukum perdata internasional (HPI) apabila terdapat unsur asing antara franchisor dan franchisee, bilamana masing-masing negara mempunyai aturan bisnis yang berlainan (Fuad. 2005).

Menurut Monroy dan Alzola (2005) menerangkan bahwa aktivitas manajerial franchise dapat digambarkan sebagai bisnis atau upaya usaha yang memfokuskan pada kepuasan konsumen melalui komitmen dengan mitra bisnis atau agen.

Kualitas relasi franchise digambarkan sebagai perincian dan kondisi organisasi dari sebuah hubungan antar perusahaan dan sebagai evaluasi menyeluruh dari kekuatan hubungan antara franchisor dan franchisee.

\section{E. Kerangka Pemikiran}

Aspek yang dapat mempengaruhi kualitas relasi franchise antara lain adalah kontrak kerjasama, aktivitas manajerial, entrepreneurship, dan branding. Aspekaspek tersebut diduga mempengaruhi kualitas relasi franchise secara langsung, dan diperkirakan semakin tinggi kualitas aspek-aspek tersebut maka akan semakin tinggi pula kualitas relasi franchise yang terbangun.

Kualitas relasi franchise berpengaruh terhadap performa franchisee. Diduga pengaruh kualitas relasi franchise berpengaruh langsung terhadap performa franchisee. Dalam studi ini berarti semakin baik kualitas relasi franchise akan meningkatkan performa penjualan franchisee.

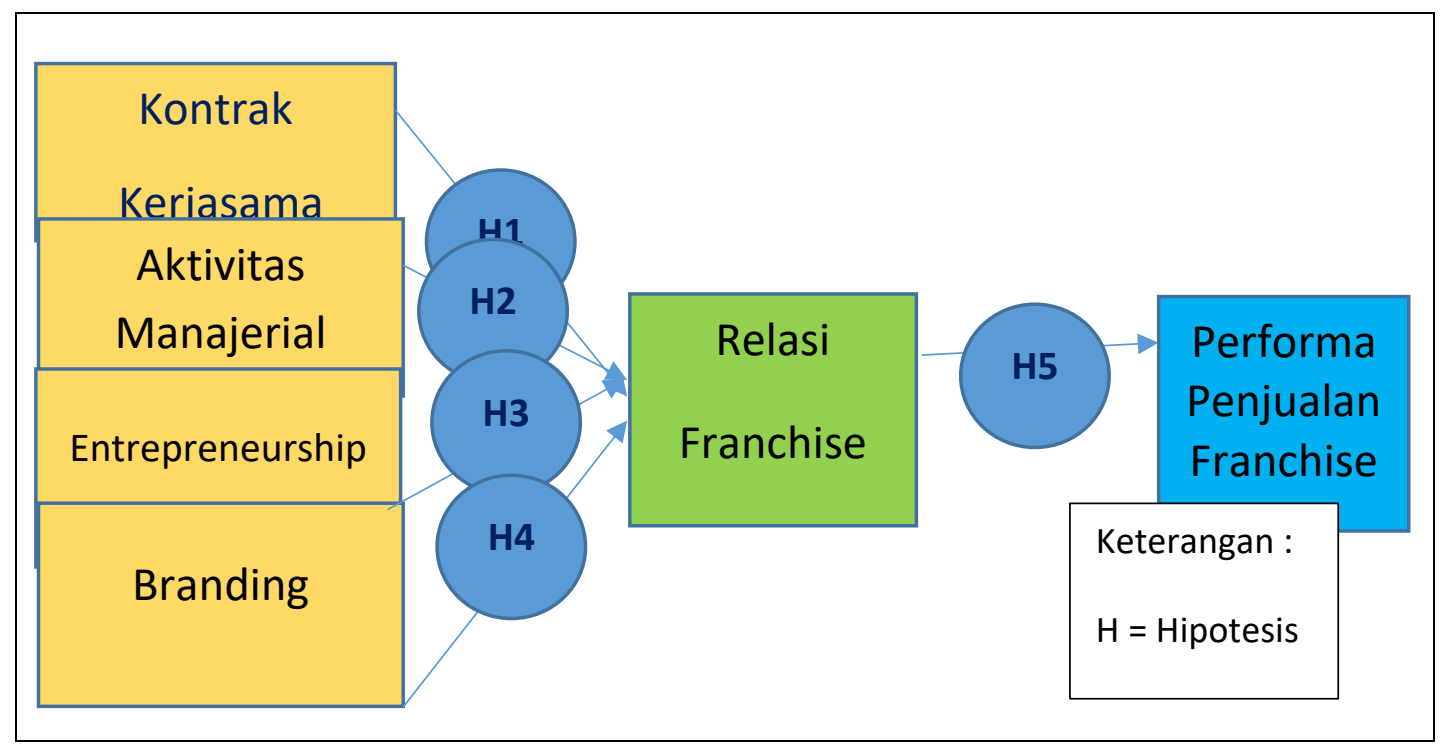

Gambar 1. Kerangka pemikiran yang dibangun dalam studi ini. 


\section{F. Metode Penelitian \\ Tempat dan Waktu Studi}

Studi dilaksanakan di daerah Jabodetabek. Studi dilaksanakan selama 5 (lima) bulan, dimulai dari bulan Maret 2018 sampai bulan Agustus 2018. Sedangkan pengolahan data dilaksanakan pada bulan September 2018.

\section{Metode}

Studi ini termasuk dalam tipe desain studi sebab - akibat yang mengidentifikasikan hubungan sebab - akibat antar variabel. Data yang diperoleh dari studi ini berupa data primer dari responden yaitu seluruh franchisee Restoran Ayam Bakar Mas Mono, Restoran Pecel Lele Lela dan Restoran Es Teler 77 di wilayah Jabodetabek.

Metode analisis yang digunakan adalah OLS (Ordinary Least Square) yang dioperasikan melalui program software SPSS 20 dan program software Lisrel 8.7 Student Version.

Model Persamaan Regresi Bertingkat dalam penelitian ini adalah :

- Hubungan Franchise $=\beta 1$ Kontrak Kerjasama $+\beta 2$ Aktivitas Manajerial +

$\beta 3$ Entrepreneurship +

$\beta 4$ Branding + e1

- Performa Penjualan Franchisee = y1 Relasi Franchise + e2

Regresi linier bertingkat dipakai dalam mengukur pengaruh variabel bebas (eksogen) terhadap variabel terikat (endogen).

\section{Populasi dan Sampel}

Pengambilan sampel yang dipakai studi ini adalah purposive sampling, yaitu penentuan sampel dipilih berdasarkan pendekatan tertentu sesuai dengan tujuan studi. Menurut Sitepu (1994), teknik purposive sampling berupa pemilihan sekelompok subyek berdasarkan atas ciri-ciri tertentu yang dipandang mempunyai hubungan yang erat dengan ciri-ciri populasi yang sudah diketahui. Melalui cara ini sampel dipilih karena faktor kondisi seperti keberadaan sampel pada tempat dan waktu yang tepat.

Responden dalam studi ini adalah pemilik, pengelola atau manajer franchisee Restoran Ayam Bakar Mas Mono, Restoran Pecel Lele Lela dan Restoran Es Teler 77 di wilayah Jabodetabek. Dari data resmi yang diperoleh dari franchisor diketahui populasi penelitian ini sebesar 119 franchisee, yang terbagi atas restoran Ayam Bakar Mas Mono sebanyak 41 franchisee, restoran Pecel Lele Lela sebanyak 27 franchisee, dan restoran Es Teler 77 sebanyak 51 franchisee.

Pendekatan Slovin digunakan untuk menentukan jumlah sampel. Dan diperoleh sampel dalam studi ini untuk restoran Ayam Bakar Mas Mono adalah 37 responden, Pecel Lele Lela adalah 25 responden, dan Es Teler 77 adalah 45 responden, dan total keseluruhan responden adalah 107 responden.

Penentuan jumlah sampel dengan menggunakan pendekatan Slovin (Umar, Husein, 2004), sebagai berikut :

$$
\begin{aligned}
& \text { diketahui }: \mathrm{n}=\text { ukuran sampel } \\
& \mathrm{n}=\frac{\mathrm{N}}{1+\mathrm{N} e^{2}} \\
& \mathrm{~N}=\text { ukuran populasi } \\
& \mathrm{e}=\text { galat pendugaan }(5 \%)
\end{aligned}
$$




\section{Metode Analisis Data \\ Uji Validitas}

Pengujian validitas ini bertujuan mengetahui apakah alat pengukuran yang digunakan memiliki validitas atau tidak. Validitas dapat diartikan sebagai apakah kuesioner tersebut mengungkapkan tingkat validitas dari populasi dan studi secara benar. (Nazir, 1998).

Uji validitas dalam studi ini menggunakan metode analisis factor dan dikalkulasi dengan software SPSS 20 Trial Version dengan membandingkan nilai faktor loading pada tabel Component Matrix melalui analisis faktor. Semakin besar nilai faktor loading item pertanyaan, maka semakin besar puluh korelasinya dengan total skor konstruk. Pada studi ini batas minimal faktor loading yang digunakan adalah 0,5.

Uji validitas dilakukan dengan membandingkan nilai r-hitung (Corrected Item Total Correlation) dengan r-tabel. Nilai r-tabel dapat diperoleh dari tabel koefisien korelasi pearson, dimana $\mathrm{df}=\mathrm{n}-2$ dalam hal ini $\mathrm{n}$ adalah jumlah sampel atau responden. Pada kasus ini jumlah sampel $(n)=15$, maka besarnya $\mathrm{df}=15-2=$ 23. Dengan alpha $=0.05$, maka didapat nilai $r$-tabel $=0.514$.

\section{Uji Reliabilitas}

Uji reliabilitas digunakan dalam mengukur tingkat kestabilan suatu alat pengukur dalam menentukan suatu kondisi. Semakin tinggi reliabilitas suatu alat pengukur, semakin baik dan stabil pula alat pengukur tersebut dan sebaliknya jika reliabilitas pengukur tersebut rendah maka alat tersebut tidak stabil dan kurang bagus dalam mengukur suatu gejala kondisi. Rumus reliabilitas dalam studi ini menggunakan pendekatan Koefisien Alpha Cronbach (Azwar. 1992).

Dengan ketentuan :

- Apabila koefisien Alpha Cronbach ( $\alpha$ ) $<0,7$ maka pertanyaan - pertanyaan dinyatakan tidak reliabel.

- Apabila koefisien Alpha Cronbach $(\alpha)>0,7$ maka pertanyaan - pertanyaan dinyatakan reliabel.

Uji Reliabilitas dilakukan dengan membandingkan nilai Alpha Cronbach's, dengan kriteria uji reliabilitas (Kaplan, 1993), jika nilai Alpha Cronbach's lebih besar dari 0.7 maka suatu instrumen dikatakan reliabel, dan jika lebih kecil dari 0.7 maka tidak reliabel.

\section{Uji Normalitas}

Uji normalitas dalam studi ini dilakukan untuk mengetahui apakah residual yang terjadi mengikuti distribusi normal atau tidak. Uji normalitas dilakukan dengan uji Kolmogorov-Smirnov. Dari hasil perhitungan normalitas untuk residual dari model analisis jalur pengaruh variabel Kontrak Kerjasama (X1), Aktivitas Manajerial (X2), Entrepreneurship (X3), Branding (X4) terhadap variabel Relasi Franchise $(Y)$ diperoleh nilai probabilitas sebesar $0.959>0.05$, dan dari model jalur Relasi Franchise (Y) terhadap Performa Penjualan Franchisee (Z) diperoleh nilai probabilitas sebesar $0.389>0.05$. Sehingga dalam studi ini dapat disimpulkan bahwa residual dari kedua model analisis jalur adalah berdistribusi normal.

\section{Pengujian Korelasi}

Sebelum dilakukan pengujian model dengan menggunakan metode analisis jalur, terlebih dahulu diperiksa hubungan antara variabel yang terkait sebagai persyaratan. Dalam studi ini jumlah variabel yang digunakan dan diperiksa hubungannya adalah sebanyak 6 (enam) variabel yaitu : Kontrak Kerjasama (K), 
Aktivitas Manajerial (M), Entrepreneurship (E), Branding (B), Relasi Franchise (R) dan Performa Penjualan Franchisee (P).

Pengukuran keeratan hubungan atau korelasi menggunakan kriteria berdasarkan Guilford (1956) :

$0.00 \leq \rho<0.20=$ korelasi sangat kecil dan bisa diabaikan

$0.20 \leq \rho<0.40=$ korelasi kecil (tidak erat)

$0.40 \leq \rho<0.70=$ korelasi moderat

$0.70 \leq \rho<0.90=$ korelasi erat

$0.90 \leq \rho<1=$ korelasi sangat erat

Uji selanjutnya menggunakan hipotesis sebagai berikut :

$\mathrm{H}_{0}$ : Tidak ada korelasi yang signifikan antara dua variabel

$\mathrm{H}_{1}$ : Ada korelasi yang signifikan antara dua variable

Dengan kriteria pengambilan keputusan berdasarkan angka signifikansi, yaitu jika signifikansi $>0.05$ maka $\mathrm{H}_{0}$ diterima, dan jika signifikansi $<0.05$ maka $\mathrm{H}_{0}$ ditolak.

\section{Analisis Data}

Setelah tahap pemilihan dan pengumpulan data penelitian maka dilakukan analisis data. Setiap studi senantiasa membutuhkan interpretasi dan analisis data, yang diharapkan mampu memberikan solusi pada research question yang menjadi dasar studi. Aalisis data menggunakan metode OLS (Ordinary Least Square) yang dioperasikan melalui program software SPSS 20 Trial Version dan program software Lisrel 8.7 Student Version.

Model Persamaan Regresi Bertingkat dalam penelitian ini adalah :

- Hubungan Franchise $=\beta 1$ Kontrak Kerjasama $+\beta 2$ Aktivitas Manajerial +

$\beta 3$ Entrepreneurship +

$\beta 4$ Branding + e1

- Performa Penjualan Franchisee = y1 Relasi Franchise + e2

Regresi linier bertingkat digunakan untuk mengetahui pengaruh variabel bebas (eksogen) terhadap variabel terikat (endogen) :

1. Pengaruh variabel eksogen Kontrak Kerjasama $(K)$ terhadap variabel endogen Relasi Franchise (R).

2. Pengaruh variabel eksogen Aktivitas Manajerial (M) terhadap variabel endogen Relasi Franchise (R).

3. Pengaruh variabel eksogen Entrepreneurship (E) terhadap variabel endogen Relasi Franchise (R).

4. Pengaruh variabel eksogen Branding terhadap (B) variabel endogen Relasi Franchise (R).

5. Pengaruh variabel endogen Relasi Franchise (HF) terhadap variabel endogen Performa Penjualan Franchisee (P).

Uji hipotesis dilakukan dengan pendekatan sebagai berikut:

1. Uji pengaruh nyata atau signifikansi variabel eksogen terhadap variabel endogen baik secara bersama-sama (serentak) maupun secara parsial (individual) dilakukan dengan uji statistik $F$ (F-test) dan uji statistik t (t-test).

Uji F-statistik

Uji ini digunakan untuk menguji keberartian pengaruh dari seluruh variabel eksogen secara bersama-sama terhadap variabel endogen.

Hipotesis dituliskan sebagai berikut:

- $\mathrm{Ha}: \beta 1, \beta 2, \beta 3, \beta 4>0$, atau $\mathrm{Ha}: \beta 1, \beta 2, \beta 3, \beta 4=0$ maka Ha diterima dan Ho ditolak, artinya terdapat pengaruh yang signifikan secara bersama-sama dari variabel eksogen terhadap variabel endogen. 
- Nilai $F_{\text {hitung }}$ dapat dicari dengan rumus:

$$
\text { Fhitung }=\frac{R 2 /(k-1)}{(1-\mathrm{R} 2) /(\mathrm{N}-\mathrm{k})}
$$

- Apabila $F_{\text {hitung }}>F_{\text {tabel }}(a, k-1, n-k)$, maka Ho ditolak dan Ha diterima atau dikatakan berpengaruh nyata atau signifikan, artinya secara bersama-sama variabel eksogen $(\mathrm{X} 1 \mathrm{~s} / \mathrm{d} \mathrm{X} 4)$ berpengaruh signifikan terhadap variabel endogen $(Y)=$ hipotesis diterima.

- Apabila $F_{\text {hitung }}<F_{\text {tabel }}(a, k-1, n-k)$, maka Ho diterima dan Ha ditolak maka dikatakan tidak berpengaruh nyata atau tidak signifikan, artinya secara bersama-sama variabel eksogen (X1 s/d X4) berpengaruh tidak nyata atau tidak signifikan terhadap variabel endogen $(Y)=$ hipotesis ditolak.

b. Uji t-statistik

Keberartian koefisien ( $\beta i)$ dilakukan dengan uji statistik-t (student-t).

Uji ini dipakai untuk menguji koefisien regresi secara parsial dari variabel eksogennya. Hipotesisnya dirumuskan sebagai berikut:

- Ha : $\beta 1>0$, atau Ho : $\beta 1=0$ maka Ha diterima dan Ho ditolak, berarti terdapat pengaruh yang nyata atau signifikan secara parsial dari variabel eksogen terhadap variabel endogen.

- Dengan $\alpha=5 \%$ maka untuk menentukan apakah pengaruhnya signifikan atau tidak, dilakukan analisis melalui peluang galatnya (p) dengan kriteria sebagai berikut :

- $\quad \mathrm{P}>0,05$ maka dinyatakan non signifikan atau Ho diterima

- 0,05 > P > 0,01 maka dinyatakan signifikan atau Ho ditolak

- $\quad \mathrm{P}<0,01$ maka dinyatakan sangat signifikan atau Ho ditolak

- Nilai t-hitung dapat dicari dengan rumus:

$$
t-\text { hitung }=\frac{\text { Koefisien regresi }(b i)}{\text { Standar Error bi }}
$$

- Jika Thitung > Ttabel (a, k - 1, n - k), maka Ho ditolak dan Ha diterima atau dikatakan berbeda nyata atau signifikan, artinya secara parsial variabel eksogen berpengaruhnyata atau signifikan terhadap variabel endogen $=$ hipotesis diterima.

- Jika Thitung < Ttabel ( $\mathrm{a}, \mathrm{k}-1, \mathrm{n}-\mathrm{k})$, maka Ho diterima dan Ha ditolak maka dikatakan tidak berpengaruh nyata atau tidak signifikan, artinya secara parsial variabel eksogen berpengaruh tidak nyata atau tidak signifikan terhadap variabel endogen = hipotesis ditolak.

Jika t-hitung $>$ t-tabel $(\alpha, n-k-1)$, maka Ho ditolak; dan Jika t-hitung $<$ t-tabel $(\alpha, n-k-1)$, maka Ho diterima.

2. Uji dominasi variabel bebas (eksogen) pada variabel terikat (endogen) dilakukan dengan membandingkan pada koefisien beta standar. 
F. HASIL DAN PEMBAHASAN

Hasil Uji Validitas dan Uji Reabilitas

Tabel 1. Hasil Pengujian Validitas dan Reliabilitas Variabel

Kontrak Kerjasama (K), Aktivitas Manajerial (M), Entrepreneurship (E), Branding (B), Relasi Franchise (R), dan Performa Penjualan Franchisee (P)

\begin{tabular}{|c|c|c|c|c|c|}
\hline Variabel & $\mathbf{r}_{\text {hitung }}$ & $\mathbf{r}_{\text {tabel }}$ & Keterangan & $\begin{array}{c}\text { Alpha } \\
\text { Cronbach's }\end{array}$ & Keterangan \\
\hline $\mathrm{K}$ & 0.678 & 0.541 & Valid & 0.872 & Reliabel \\
\hline $\mathrm{M}$ & 0.678 & 0.541 & Valid & 0.933 & Reliabel \\
\hline $\mathrm{E}$ & 0.717 & 0.541 & Valid & 0.894 & Reliabel \\
\hline $\mathrm{B}$ & 0.732 & 0.541 & Valid & 0.853 & Reliabel \\
\hline $\mathrm{R}$ & 0.657 & 0.541 & Valid & 0.862 & Reliabel \\
\hline $\mathrm{P}$ & 0.624 & 0.541 & Valid & 0.805 & Reliabel \\
\hline
\end{tabular}

Hasil Uji Normalitas

Dari hasil perhitungan normalitas untuk residual dari model analisis jalur pengaruh variabel Kontrak Kerjasama (K), Aktivitas Manajerial (M), Entrepreneurship (E), Branding (B) terhadap variabel Relasi Franchise $(R)$ diperoleh nilai probabilitas sebesar $0.959>0.05$, dan dari model jalur Relasi Franchise $(R)$ terhadap Performa Penjualan Franchisee $(P)$ diperoleh nilai probabilitas sebesar $0.389>0.05$. Sehingga dapat disimpulkan bahwa residual dari kedua model analisis jalur adalah berdistribusi normal.

Tabel 2. Hasil Uji Normalitas dengan Uji Kolmogorov-Smirnov

\begin{tabular}{|l|c|}
\hline \multicolumn{1}{|c|}{ Model } & Signifikasi \\
\hline$R=>K M E B$ & 0.959 \\
\hline$P=>R$ & 0.389 \\
\hline
\end{tabular}

Pengujian Korelasi

Tabel 3. Pengujian Hubungan Antar Sub Variabel

\begin{tabular}{|c|c|c|c|c|c|}
\hline \multicolumn{2}{|c|}{ Hubungan } & \multirow{2}{*}{$\begin{array}{l}\text { Koefisie } \\
\mathbf{n} \\
\text { Korelasi }\end{array}$} & \multirow{2}{*}{ Kategori } & \multirow{2}{*}{ Sig. } & \multirow{2}{*}{$\underset{\mathbf{n}}{\text { Kesimpula }}$} \\
\hline Variabel 1 & Variabel 2 & & & & \\
\hline $\begin{array}{l}\text { Kontrak } \\
\text { Kerjasama }\end{array}$ & $\begin{array}{l}\text { Aktivitas } \\
\text { Manajerial }\end{array}$ & 0.532 & Moderat & 0.000 & Signifikan \\
\hline $\begin{array}{l}\text { Kontrak } \\
\text { Kerjasama }\end{array}$ & Entrepreneurship & 0.371 & Tidak Erat & 0.000 & Signifikan \\
\hline $\begin{array}{l}\text { Kontrak } \\
\text { Kerjasama }\end{array}$ & Branding & 0.308 & Tidak Erat & 0.000 & Signifikan \\
\hline $\begin{array}{l}\text { Kontrak } \\
\text { Kerjasama }\end{array}$ & Relasi Franchise & 0.631 & Moderat & 0.000 & Signifikan \\
\hline $\begin{array}{l}\text { Kontrak } \\
\text { Kerjasama }\end{array}$ & $\begin{array}{l}\text { Performa } \\
\text { Penjualan } \\
\text { Franchisee }\end{array}$ & 0.467 & Moderat & 0.000 & Signifikan \\
\hline $\begin{array}{l}\text { Aktivitas } \\
\text { Manajemen }\end{array}$ & Entrepreneurship & 0.403 & Moderat & 0.000 & Signifikan \\
\hline
\end{tabular}


Manajemen Pemasaran ISSN N•. (PRINT) 2598-0823, (ONLINE) 2598-2893

\begin{tabular}{|l|l|c|c|c|c|}
\hline $\begin{array}{l}\text { Aktivitas } \\
\text { Manajemen }\end{array}$ & Branding & 0.322 & Tidak Erat & 0.000 & Signifikan \\
\hline $\begin{array}{l}\text { Aktivitas } \\
\text { Manajemen }\end{array}$ & Relasi Franchise & 0.622 & Moderat & 0.000 & Signifikan \\
\hline $\begin{array}{l}\text { Aktivitas } \\
\text { Manajemen }\end{array}$ & $\begin{array}{l}\text { Performa } \\
\text { Penjualan } \\
\text { Franchisee }\end{array}$ & 0.441 & Moderat & 0.000 & Signifikan \\
\hline $\begin{array}{l}\text { Entrepreneurs } \\
\text { hip }\end{array}$ & Branding & 0.444 & Moderat & 0.000 & Signifikan \\
\hline $\begin{array}{l}\text { Entrepreneurs } \\
\text { hip }\end{array}$ & Relasi Franchise & 0.559 & Moderat & 0.000 & Signifikan \\
\hline $\begin{array}{l}\text { Entrepreneurs } \\
\text { hip }\end{array}$ & $\begin{array}{l}\text { Performa } \\
\text { Penjualan } \\
\text { Franchisee }\end{array}$ & 0.469 & Moderat & 0.000 & Signifikan \\
\hline Branding & Relasi Franchise & 0.561 & Moderat & 0.000 & Signifikan \\
\hline Branding & $\begin{array}{l}\text { Performa } \\
\text { Penjualan } \\
\text { Franchisee }\end{array}$ & 0.498 & Moderat & 0.000 & Signifikan \\
\hline $\begin{array}{l}\text { Relasi } \\
\text { Franchise }\end{array}$ & $\begin{array}{l}\text { Performa } \\
\text { Penjualan } \\
\text { Franchisee }\end{array}$ & 0.627 & Moderat & 0.000 & Signifikan \\
\hline
\end{tabular}

Berdasarkan hasil pengujian di atas diketahui bahwa terdapat 15 pengujian hubungan antar variabel penelitian. Dari 15 pengujian korelasi, tiga diantaranya memiliki nilai koefisien korelasi yang berada pada kisaran $0.20 \leq \rho<0.40$ dengan nilai signifikansi yang lebih kecil dari 0.05 . Hal ini menunjukkan bahwa hubungan antar variabel penelitian memiliki hubungan yang kurang erat dan hubungan tersebut sangat signifikan. Selain itu 12 diantaranya memiliki nilai koefisien korelasi yang berada pada kisaran $\quad 0.40 \leq \rho<0.70$ dengan nilai signifikansi yang lebih kecil dari 0.05. Hal ini menunjukkan bahwa hubungan antar variabel penelitian memiliki hubungan yang cukup erat dan hubungan tersebut sangat signifikan.

\section{Hasil Analisis Data}

Menggunakan bantuan software LISREL 8.7 Student Version, diperoleh nilai koefisien dari analisis jalur yang diajukan untuk keseluruhan franchisee sebagai berikut :

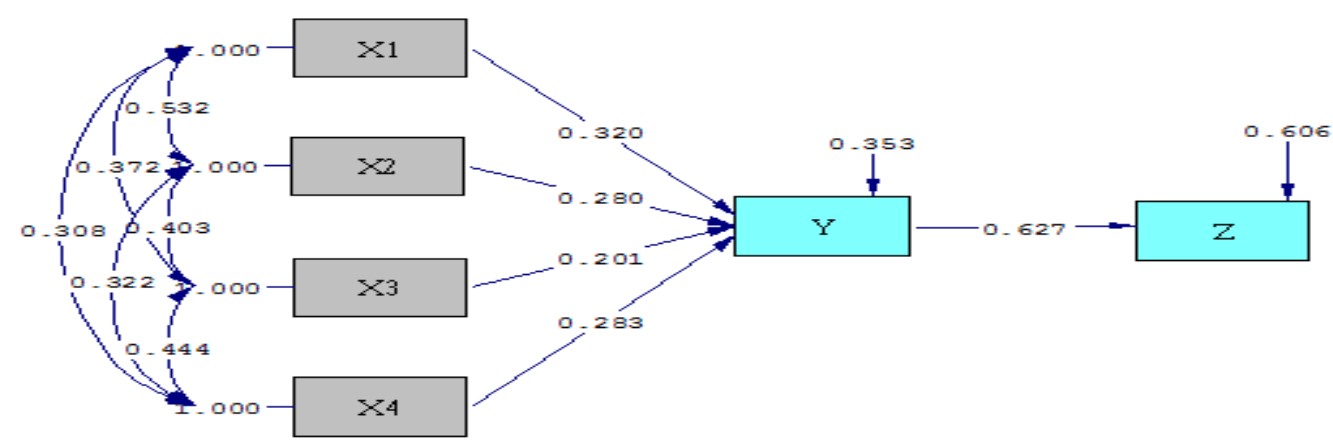

Gambar 2. Koefisien Jalur dari Keseluruhan Franchisee 
Dari gambar jalur di atas, maka didapatkan dua persamaan analisis jalur dimana variabel Kontrak Kerjasama ( X1), Aktivitas Manajerial (X2), Entrepreneurship (X3) dan Branding (X4) merupakan empat buah variabel bebas (eksogen) yang satu dengan yang lainnya mempunyai kaitan korelatif secara bersama-sama mempengaruhi variable terikat (endogen) Relasi Franchise ( $\mathrm{Y}$ ) dan variabel terikat (endogen) Relasi Franchise (Y) mempengaruhi variable terikat (endogen) Performa Penjualan Franchisee (Z).

Berikut adalah persamaan jalur tersebut :

$Y=0.320 X_{1}+0.280 X_{2}+0.201 X_{3}+0.283 X_{4}+\varepsilon:$ dan $Z=0.627 Y+\varepsilon_{2}$

Persamaan analisis jalur untuk Franchisee Ayam Bakar Mas Mono adalah :

$$
Y=0.407 X_{1}+0.260 X_{2}+0.182 X_{3}+0.357 X_{4}+\varepsilon: \text { dan } Z=0.863 Y+\varepsilon_{2}
$$

Persamaan Analisis Jalur untuk Franchisee Pecel Lele Lela adalah :

$$
Y=-0.023 X_{1}+0.328 X_{2}+0.410 X_{3}+0.360 X_{4}+\varepsilon: \text { dan } Z=0.358 Y+\varepsilon_{2}
$$

Persamaan Analisis Jalur untuk Franchisee Es Teler 77 adalah :

$$
Y=0.446 X_{1}+0.250 X_{2}+0.132 X_{3}+0.272 X_{4}+\varepsilon: \text { dan } Z=0.753 Y+\varepsilon_{2}
$$

\section{Pengujian Koefisien Persamaan Analisis Jalur Secara Simultan Tabel 4. Pengujian Simultan Pengaruh Kontrak Kerjasama

\begin{tabular}{|c|c|c|c|c|c|c|}
\hline Model & & $\begin{array}{l}\text { Sum of } \\
\text { Squares }\end{array}$ & $\mathrm{df}$ & $\begin{array}{c}\text { Mean } \\
\text { Square }\end{array}$ & $F$ & Sig. \\
\hline \multirow[t]{3}{*}{1} & Regression & 164.042 & 4 & 41.011 & 46.753 & $.000^{a}$ \\
\hline & Residual & 89.472 & 102 & .877 & & \\
\hline & Total & 253.514 & 106 & & & \\
\hline
\end{tabular} Aktivitas Manajerial, Entrepreneurship dan Branding terhadap Relasi Franchise}

a. Predictors: (Constant), X4, X1, X3, X2

Dari penghitungan didapat nilai Fhitung sebesar 46.753. Dengan tingkat signifikansi sebesar $5 \%$ serta $\mathrm{df}_{1}=4$ dan $\mathrm{df}_{2}=102$, didapat nilai $F_{\text {tabel }}=2.461$. Karena nilai $F_{\text {hitung }}(46.753)>$ nilai $F_{\text {tabel }}(2.461)$ maka $\mathrm{H}_{0}$ ditolak atau terdapat kecocokan antara model dengan data. Sehingga dapat disimpulkan bahwa aspek variabel Kontrak Kerjasama, Aktivitas Manajerial, Entrepreneurship dan Branding secara simultan berpengaruh signifikan terhadap Relasi Franchise. Sehingga model analisis jalur yang didapatkan layak digunakan untuk pengujian simultan persamaan kedua dari pengaruh Relasi Franchise terhadap Performa Penjualan Franchisee. Sedangkan rekapitulasi hasil perhitungan pengujian simultan persamaan kedua disajikan pada Tabel 5.

Tabel 5. Pengujian Simultan Pengaruh Hubungan Franchise terhadap Kinerja Penjualan Franchisee

\begin{tabular}{|ll|r|r|r|r|r|}
\hline \multicolumn{1}{|c|}{} & \multicolumn{1}{c|}{$\begin{array}{c}\text { Sum of } \\
\text { Model }\end{array}$} & \multicolumn{1}{c|}{$\begin{array}{c}\text { Mean } \\
\text { Squares }\end{array}$} & \multicolumn{1}{c|}{$\mathrm{df}$} & Square & \multicolumn{1}{c|}{$\mathrm{F}$} & Sig. \\
\hline 1 & Regression & 188.266 & 1 & 188.266 & 68.170 & $.000^{\mathrm{a}}$ \\
& Residual & 289.977 & 105 & 2.762 & & \\
& Total & 478.243 & 106 & & & \\
\hline
\end{tabular}

a. Predictors: (Constant), Y 
Dari penghitungan didapat nilai $\mathrm{F}$ hitung sebesar 68.17. Dengan tingkat

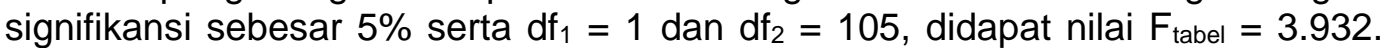
Karena nilai $F_{\text {hitung }}(68.17)>$ nilai $F_{\text {tabel }}$ (3.932) maka $\mathrm{H}_{0}$ ditolak atau terdapat kecocokan antara model dengan data. Sehingga dapat disimpulkan bahwa aspek variabel Relasi Franchise secara simultan berpengaruh signifikan terhadap Performa Penjualan Franchisee. Sehingga model analisis jalur yang didapatkan layak digunakan.

\section{Pengujian Koefisien Persamaan Analisis Jalur Secara Parsial}

Pengujian parsial dianalisis terhadap model untuk keseluruhan franchisee dan untuk masing-masing franchisee.

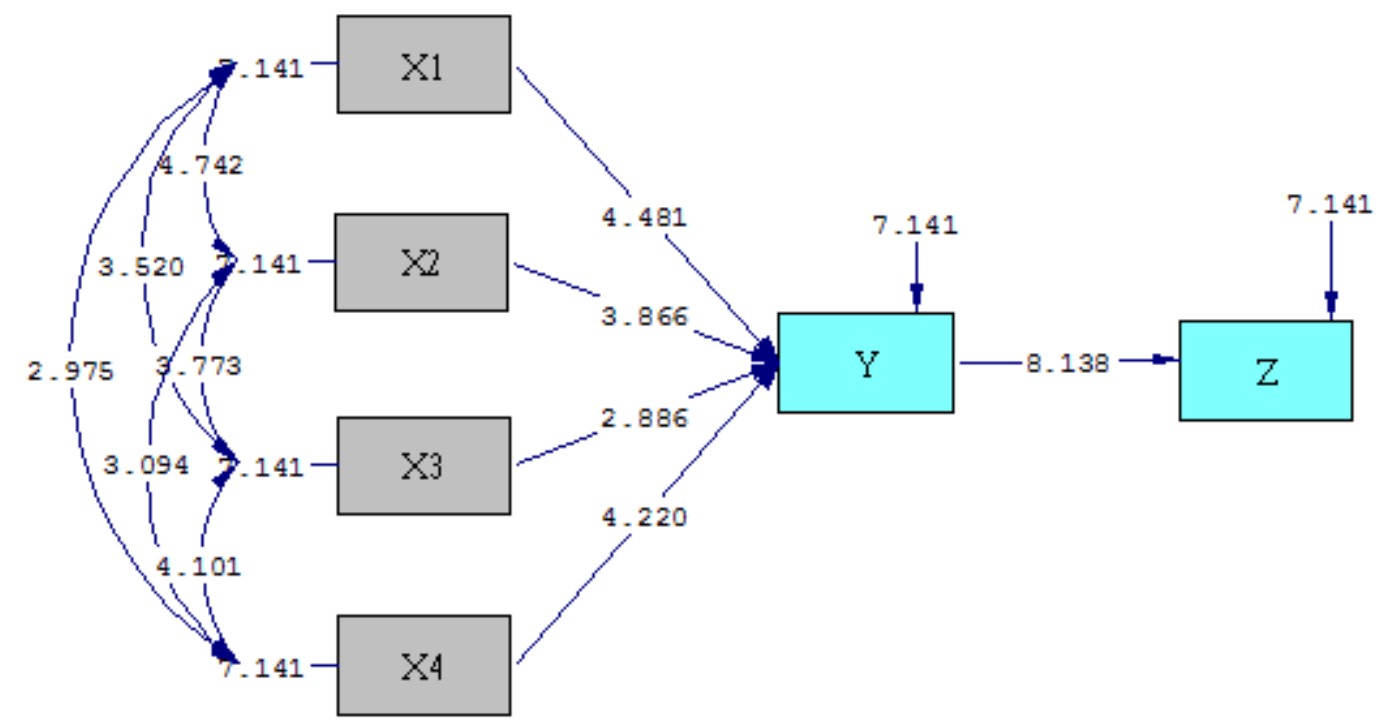

\section{Gambar 3. Nilai t hitung dari Keseluruhan Franchisee}

Pengambilan keputusan didasarkan atas perbandingan nilai $t_{\text {hitung }}$ dengan $t_{\text {tabel }}$ di mana $\mu_{1}=\mu_{2}$ dengan $\alpha=0.05$, karena digunakan hipotesis dua arah, ketika mencari $t_{\text {tabel}}$, nilai a dibagi dua menjadi 0.025, dan $\mathrm{df}=105$ (didapat dari rumus $\mathrm{n}-2$, dimana $\mathrm{n}$ adalah jumlah data, $107-2=105$ ), didapat tabel adalah 1.983 .

Dengan kriteria sebagai berikut :

Jika $\left|t_{\text {hitung }}\right|>t_{\text {tabel}}$, maka $\mathrm{H}_{0}$ ditolak

Jika $\left|t_{\text {nitung }}\right|<\mathrm{t}_{\text {tabel }}$, maka $\mathrm{H}_{0}$ diterima

Berdasarkan hasil pengujian diketahui bahwa kelima koefisien jalur memiliki keputusan dimana $\mathrm{H}_{0}$ ditolak. Maka dapat ditarik kesimpulan, yaitu seluruh koefisien jalur memiliki pengaruh signifikan terhadap variabel endogennya.

\section{Mono}

Pengujian Parsial Koefisien Jalur Untuk Franchisee Ayam Bakar Mas

Ringkasan hasil perhitungan dan pengujian pengaruh koefisien jalur dari variable bebas (eksogen) terhadap variabel terikat (endogen) ditampilkan pada Tabel 6. 
Tabel 6. Ringkasan dan Pengujian Koefisien Jalur pada

Franchisee Ayam Bakar Mas Mono

\begin{tabular}{|c|c|c|c|c|c|}
\hline No & $\begin{array}{l}\text { Koefisien } \\
\text { Jalur }\end{array}$ & Hipotesis & $t_{\text {hitung }}$ & Keputusan & Kesimpulan \\
\hline 1 & $\rho_{y x 1}=0.407$ & $\begin{array}{l}H_{0}: \rho_{y x 1}=0 \\
H_{1}: \rho_{y x 1} \neq 0\end{array}$ & 4.203 & $\mathrm{H}_{0}$ Ditolak & $\begin{array}{l}\text { Memiliki pengaruh } \\
\text { signifikan }\end{array}$ \\
\hline 2 & $\rho_{y x 2}=0.260$ & $\begin{array}{l}H_{0}: \rho_{y \times 2}=0 \\
H_{1}: \rho_{y x 2} \neq 0\end{array}$ & 2.785 & $\mathrm{H}_{0}$ Ditolak & $\begin{array}{l}\text { Memiliki pengaruh } \\
\text { signifikan }\end{array}$ \\
\hline 3 & $\rho_{y x 3}=0.182$ & $\begin{array}{l}\mathrm{H}_{0}: \rho_{\mathrm{yx} 3}=0 \\
\mathrm{H}_{1}: \rho_{\mathrm{yx} 3} \neq 0\end{array}$ & 1.680 & $\mathrm{H}_{0}$ Diterima & $\begin{array}{l}\text { Tidak berpengaruh } \\
\text { signifikan }\end{array}$ \\
\hline 4 & $\rho_{y x 4}=0.357$ & $\begin{array}{l}H_{0}: \rho_{y x 4}=0 \\
H_{1}: \rho_{y x 4} \neq 0\end{array}$ & 2.886 & $\mathrm{H}_{0}$ Ditolak & $\begin{array}{l}\text { Memiliki pengaruh } \\
\text { signifikan }\end{array}$ \\
\hline 5 & $\rho_{z y}=0.863$ & $\begin{array}{l}\mathrm{H}_{0}: \rho_{z y}=0 \\
\mathrm{H}_{1}: \rho_{z y} \neq 0\end{array}$ & 9.667 & $\mathrm{H}_{0}$ Ditolak & $\begin{array}{l}\text { Memiliki pengaruh } \\
\text { signifikan }\end{array}$ \\
\hline
\end{tabular}

Berdasarkan hasil pengujian pada tabel di atas diketahui bahwa variabel Kontrak Kerjasama, Aktivitas Manajerial dan Branding berpengaruh signifikan terhadap variabel Relasi Franchise serta variabel Relasi Franchise berpengaruh signifikan terhadap variabel Performa Penjualan Franchisee. Sedangkan variabel Entrepreneurship tidak berpengaruh signifikan terhadap variabel Relasi Franchise pada franchisee Ayam Bakar Mas Mono.

Pengujian Parsial Koefisien Jalur Untuk Franchisee Pecel Lele Lela

Ringkasan hasil perhitungan dan pengujian pengaruh koefisien jalur dari variabel bebas (eksogen) terhadap variabel terikat (endogen) ditampilkan pada Tabel 7 di bawah ini.

Tabel 7. Ringkasan dan Pengujian Koefisien Jalur pada

Franchisee Pecel Lele Lela

\begin{tabular}{|l|l|l|l|l|l|}
\hline No & $\begin{array}{l}\text { Koefisien } \\
\text { Jalur }\end{array}$ & Hipotesis & t thitung & Keputusan & Kesimpulan \\
\hline 1 & $\rho_{y x 1}=-0.023$ & $\begin{array}{l}\mathrm{H}_{0}: \rho_{\mathrm{yx} 1}=0 \\
\mathrm{H}_{1}: \rho_{\mathrm{yx} 1} \neq 0\end{array}$ & -0.099 & $\mathrm{H}_{0}$ Diterima & $\begin{array}{l}\text { Tidak berpengaruh } \\
\text { signifikan }\end{array}$ \\
\hline 2 & $\rho_{y x 2}=0.328$ & $\begin{array}{l}\mathrm{H}_{0}: \rho_{\mathrm{yx} 2}=0 \\
\mathrm{H}_{1}: \rho_{\mathrm{yx} 2} \neq 0\end{array}$ & 1.923 & $\mathrm{H}_{0}$ Diterima & $\begin{array}{l}\text { Tidak berpengaruh } \\
\text { signifikan }\end{array}$ \\
\hline 3 & $\rho_{y x 3}=0.410$ & $\begin{array}{l}\mathrm{H}_{0}: \rho_{\mathrm{yx} 3}=0 \\
\mathrm{H}_{1}: \rho_{\mathrm{yx} 3} \neq 0\end{array}$ & 1.855 & $\mathrm{H}_{0}$ Diterima & $\begin{array}{l}\text { Tidak berpengaruh } \\
\text { signifikan }\end{array}$ \\
\hline 5 & $\rho_{y x 4}=0.360$ & $\begin{array}{l}\mathrm{H}_{0}: \rho_{\mathrm{yx} 4}=0 \\
\mathrm{H}_{1}: \rho_{\mathrm{yx} 4} \neq 0\end{array}$ & 2.088 & $\mathrm{H}_{0}$ Ditolak & $\begin{array}{l}\text { Memiliki pengaruh } \\
\text { signifikan }\end{array}$ \\
\hline 5 & $\rho_{z y}=0.358$ & $\begin{array}{l}\mathrm{H}_{0}: \rho_{z y}=0 \\
\mathrm{H}_{1}: \rho_{z y} \neq 0\end{array}$ & 1.717 & $\mathrm{H}_{0}$ Diterima & $\begin{array}{l}\text { Tidak berpengaruh } \\
\text { signifikan }\end{array}$ \\
\hline
\end{tabular}

Hasil pengujian pada Tabel 7 di atas diketahui bahwa variabel Kontrak Kerjasama, Aktivitas Manajerial dan Entrepreneurship tidak berpengaruh signifikan terhadap variabel Relasi Franchise, serta variabel Relasi Franchise tidak berpengaruh signifikan terhadap variabel Performa Penjualan Franchisee. Hanya variabel Branding yang berpengaruh signifikan terhadap variabel Relasi 
Franchise pada franchisee Pecel Lele Lela.

Pengujian Parsial Koefisien Jalur Untuk Franchisee Es Teler 77

Hasil perhitungan dan pengujian pengaruh koefisien jalur dari variabel bebas (eksogen) terhadap variabel terikat (endogen) disajikan pada Tabel 8.

Tabel 8. Ringkasan dan Pengujian Koefisien Jalur pada

Franchisee Es Teler 77

\begin{tabular}{|l|l|l|l|l|l|}
\hline No & Koefisien Jalur & Hipotesis & thitung & Keputusan & Kesimpulan \\
\hline 1 & $\rho_{y x 1}=0.446$ & $\begin{array}{l}\mathrm{H}_{0}: \rho_{\mathrm{yx} 1}=0 \\
\mathrm{H}_{1}: \rho_{\mathrm{yx} 1} \neq 0\end{array}$ & 4.431 & $\mathrm{H}_{0}$ Ditolak & $\begin{array}{l}\text { Memiliki pengaruh } \\
\text { signifikan }\end{array}$ \\
\hline 2 & $\rho_{y x 2}=0.250$ & $\begin{array}{l}\mathrm{H}_{0}: \rho_{\mathrm{yx} 2}=0 \\
\mathrm{H}_{1}: \rho_{\mathrm{yx} 2} \neq 0\end{array}$ & 2.232 & $\mathrm{H}_{0}$ Ditolak & $\begin{array}{l}\text { Memiliki pengaruh } \\
\text { signifikan }\end{array}$ \\
\hline 3 & $\rho_{y x 3}=0.132$ & $\begin{array}{l}\mathrm{H}_{0}: \rho_{\mathrm{yx} 3}=0 \\
\mathrm{H}_{1}: \rho_{\mathrm{yx} 3} \neq 0\end{array}$ & 1.244 & $\begin{array}{l}\mathrm{H}_{0} \\
\text { Diterima }\end{array}$ & $\begin{array}{l}\text { Tidak berpengaruh } \\
\text { signifikan }\end{array}$ \\
\hline 5 & $\rho_{y x 4}=0.272$ & $\begin{array}{l}\mathrm{H}_{0}: \rho_{\mathrm{yx} 4}=0 \\
\mathrm{H}_{1}: \rho_{\mathrm{yx} 4} \neq 0\end{array}$ & 3.041 & $\mathrm{H}_{0}$ Ditolak & $\begin{array}{l}\text { Memiliki pengaruh } \\
\text { signifikan }\end{array}$ \\
\hline$\rho_{z y}=0.753$ & $\begin{array}{l}\mathrm{H}_{0}: \rho_{z y}=0 \\
\mathrm{H}_{1}: \rho_{z y} \neq 0\end{array}$ & 7.227 & $\mathrm{H}_{0}$ Ditolak & $\begin{array}{l}\text { Memiliki pengaruh } \\
\text { signifikan }\end{array}$ \\
\hline
\end{tabular}

Diketahui bahwa variabel Kontrak Kerjasama, Aktivitas Manajerial dan Branding berpengaruh signifikan terhadap variabel Relasi Franchise, serta variabel Relasi Franchise berpengaruh signifikan terhadap variabel Performa Penjualan Franchisee. Hanya variabel Entrepreneurship yang tidak berpengaruh signifikan terhadap variabel Relasi Franchise pada franchisee Es Teler 77.

\section{Kesimpulan}

Berdasarkan hasil penghitungan secara statistik dan pembahasan studi yang mengacu kepada perumusan masalah dan hipotesis, maka dapat disimpulkan hal-hal sebagai berikut :

1. Angka koefisien korelasi antar variabel bertanda positif $(+)$, hal itu menunjukkan hubungan antar variabel tersebut bersifat berbanding lurus, artinya peningkatan satu variabel akan diikuti oleh variabel yang lain. Korelasi positif itu signifikan untuk semua hubungan variabel, dan berada pada kategori tidak erat dan moderat. Hal itu membuktikan bahwa hasil yang didapat dalam studi ini sesuai dengan hipotesisnya, yaitu semakin baik nilai kontrak kerjasama, aktivitas manajerial, entrepreneurship, dan branding maka akan semakin baik pula nilai relasi franchise, dan semakin baik nilai relasi franchise maka akan semakin baik pula nilai performa penjualan franchisee.

2. Entrepreneurship merupakan faktor yang harus diperhatikan oleh semua franchisee apabila relasi franchise dan performa penjualan franchisee diharapkan meningkat dengan baik.

3. Branding pada semua franchisee menunjukkan hasil yang baik. Faktor merek dalam bisnis franchise merupakan modal yang sangat penting bagi peningkatan relasi franchise dan performa penjualan franchisee.

4. Faktor kontrak kerjasama dan aktivitas manajerial merupakan faktor yang harus terus ditingkatkan bagi semua franchisee, terutama bagi franchisee Pecel Lele Lela. Hal tersebut karena kontrak kerjasama merupakan jembatan kerjasama antara franchisor dan franchisee, sedangkan aktivitas 
manajerial adalah motor penggerak bagi kelangsungan hidup dan kemajuan bisnis franchise.

5. Hasil pengujian koefisien jalur secara parsial dan hasil uji pengaruh langsung dan tidak langsung variabel eksogen terhadap variabel endogen, maka dapat dilihat bahwa aspek-aspek yang berpengaruh terhadap relasi franchise dan performa penjualan franchisee, menunjukkan hasil terbaik pada franchisee Ayam Bakar Mas Mono, kemudian franchisee Es Teler 77

\section{Saran} Pecel Lele Lela, dan terakhir pada franchisee Pecel Lele Lela.

1. Motivasi entrepreneurship yang terprogram secara baik oleh franchisor sangat diperlukan oleh semua franchisee, baik franchisee Ayam Bakar Mas Mono, Es Teler 77, maupun Pecel Lele Lela, dalam rangka meningkatkan relasi franchise dan meningkatkan performa penjualan franchisee. Motivasi oleh franchisor itu dapat berupa training atau pemberian bonus finansial yang diberikan kepada franchisee yang berprestasi.

2. Diperlukan penelitian lebih lanjut terhadap aspek motivasi kewirausahaan pada franchisor maupun franchisee. Penelitian itu terutama ditujukan untuk mengetahui motif motivasi finansial dan non finansial dalam hubungan franchise. Hasil penelitian itu nantinya diharapkan dapat menjadi acuan bagi franchisor maupun franchisee dalam memberi motivasi yang efektif bagi peningkatan kinerja franchise.

\section{G. DAFTAR PUSTAKA}

Baron, S. and Schmidt, R., 1991. "Operational Aspects of Retail Franchises". International Journal of Retail and Distribution Management, 19 (2), 13-19.

Bradach L., Jeffrey. 1998. Franchise Organization. Harvard Business School, Boston.

Fuady, Munir. 2005. Pengantar Hukum Bisnis. PT. Citra Aditya Bakti, Bandung.

Morrison, 1997, How Franchise Job Satisfaction and Personality Affects Performance, Organizational Commitment, Franchisor Relations, and Intention To Remain. European Journal Of Marketing Vol.35,pg.39

Nazir, M. 2005. Metode Penelitian. Ghalia Indonesia. Bogor

Sitepu, Nirwana SK. 1994. Analisis Jalur. FMIPA Universitas Pajajaran, Bandung.

Sukandar, Anang. 2006. Franchising di Indonesia. Asosiasi Franchise Indonesia, Jakarta 